\title{
Significance of the Authentic Ambience of the Petrovaradin Fortress on the Attractiveness of EXIT Festival
}

\author{
Snežana Besermenji', Tatjana Pivac', Ksenija Wallrabenstein' \\ Received: January 2009 | Revised: May 2009 | Accepted: May 2009
}

\begin{abstract}
Festivals have become the most widely spread type of modern special events as well as the fastest growing tourist attractions. For the past eight (nine in July 2008) years Novi Sad has been hosting one of the largest, or even the largest international event in Serbia, which attracts over 200,000 visitors, half of which are foreign visitors. Music festival EXIT, takes place at the Petrovaradin Fortress, a spatial and cultural entity, which is also among cultural assets of the highest importance. The Petrovaradin Fortress becomes the centre of youth, culture and art during the festival.Every year EXIT festival turns the Fortress into the central spot of cultural tourism in Serbia, as well as the point where different cultures meet and new friendships are born.
\end{abstract}

Key words: Novi Sad, festival, Petrovaradin fortress, authentic ambience

\section{Introduction}

Events stand for significant stimuli and prominent forms within the development and marketing plan of numerous destinations. The role and the impact of event planning in tourism is well-rated and of growing influence concerning the destinations' competition. It has been only several decades since "event based tourism" strengthened its position within both tourism and science (Getz, 2007). Event based tourism has been explained by Getz as systematic planning, development and marketing of festivals and special events as tourist attractions. It has been a development catalyst and portrait of the destination attractiveness for those managing the destination (Getz, 1997). Utilization of main events and festivals as tourism generators has been an international trend (Stokes, 2008).

Contemporary tourism development has shown that there is greater interrelation between city and cultural tourism as well as the maintaining the trend of growing cultural content in tourist offers of cities. Certain cities, due to the lack of important attractions found the solution in specific forms of cultural tourism, primarily based on festivals (Hadzic, 2005).

According to Cultural Festival Group (Association for Tourism and Leisure Education, 2003), festivals (events) are "greater opportunities for a society, a family, an individual to express their identities, lifestyles, social relations and the sense of belonging". As Getz quotes, the festival "include large number of different events, including sports events, concerts, recreation, sponsor's product presentation and selling, as well as educational content programmes" (Getz, 1997).

UNEP highlights that festivals contribute largely to the development of cultural tourism, since they have been greatly adjusted to the visitors' needs, with the aim of offering diverse experience (www.uneptie.org/pc/tourism).

Not only the festivals attract visitors to the venue, but they also contribute to the "creating a positive image of the destination, enriching tourist experience, and increasing their length of stay" (Baum, T, Hagen L, 1999).

Every year, tourists spend a lot of time and money worldwide to visit festivals. The events such as New Orleans's Mardi Gras, Rio de Janeiro's Carnival, numerous jazz festivals, etc. attract visitors from all over the world for their cultural content. The festivals are new and alternative forms of tourism and valuable marketing events for the region and its tourism industry. The events need to be promoted, well organized and well managed in order to grant visitors enjoyment and pleasure during the festival (Lee, Lee, Lee and Babin, 2008). 
Furthermore, festivals contribute to the forming of versatile tourist offer, since they create possibility of getting to know the local community while celebrating its culture. Festivals are visited by the local people who feel proud of their identity during the festival. Frequently, the festivals intended for the local people gradually become highly attractive for tourists from distant countries.

Currently, the increase in number of festival is the feature of medium size and small towns, with the example of Edinburgh, which became a significant tourist destination, owing to numerous festivals, which are held there. Thus, the City Council of Edinburgh 1999/2000 invested over $£ 5.5$ million in support of over 50 festivals in Edinburgh, which had the economic impact of $£ 119$ million according to the estimations of economists (Hadzic, 2005).

The most famous festival in Serbia is EXIT festival, held in Novi Sad. The festival is a major music event with the performers from Serbia, the region and the world. The most popular celebrities of the music world have taken part in EXIT festival for the last nine years. The festival attracts the young from the country, the region (former Yugoslav republics), Europe and the world. The number of visitors increases every year, as well as their length of stay (extending to a whole month) after the festival.

\section{EXIT Festival}

EXIT festival emerged within the students' movement that fought for democratic changes in Serbia at the end of $20^{\text {th }}$ century, now run by the consortium of nongovernmental organizations and enterprises. The festival was organized for the first time in 2000 at the local level, growing into one of the largest music and cultural festivals in southeastern Europe in 2001.

EXIT festival is one of the largest cultural and social projects in Serbia within the last decade. Its concept resembles modern European festivals but presents its unique mixture of great music, theatre and film festivals, lectures, platforms and other performances.

The festival is held at the Petrovaradin Fortress in Novi Sad, which becomes the centre of youth, culture and art. Every year EXIT makes the Fortress the heart of cultural tourism in Serbia, as well as the meeting point of different cultures and friendships.

In the autumn of 2007, EXIT festival was ranked first in its category in Europe in the review of 40 festivals. The large number of visitors came from Great Britain owing to the article in the Observer newspaper, which wrote about EXIT as the best festival in the world (www.myexit.org/ node/62613).

Furthermore, EXIT festival was awarded the best event at "SeeMe" Awards at the conference, which took place on $7^{\text {th }}$ June 2008 in Sofia. "South East Europe Music Event" is both the festival of electronic music and the conference for organisations and individuals in the electronic music business in South Eastern Europe. It has taken place in Sofia since 2006, and SeeMe awards have been awarded since 2008. The festival organization selects nominees in 17 categories, and the winners are chosen by the pub- lic via Internet balloting (http://www.blic.rs/forum/index. php?topic $=2682.0$ ).

The leading world's magazine for electronic music "DJ" within the festival 2008 section devoted the largest space to EXIT festival by asking a question: What makes the festival that attractive? The magazine team admitted that EXIT festival is among their favourites and searched for the answers among the festival visitors from the UK whose preference was a venue (the Petrovaradin fortress) thousands of kilometres away from their home, instead of numerous venues in their neighbourhood. The British visitors answered the following: The major attractions are people, programme, weather conditions, venue and prices. The programme is magnificent, with outstanding production. The panoramic view of the town from the fortress is a unique quality of the festival. The sun is almost guaranteed, the people are in good mood and everything is much cheaper than in England. Almost all the interviewed visitors highlighted that EXIT festival was "an extraordinary experience" for them. Moreover, all of them decided to visit Novi Sad, since their friends had only positive attitudes towards EXIT festival (http://www. vesti.rs/Kultura/Caskanje-na-Tvrdjavi-The-Bellrays.html).

The Petrovaradin Fortress, as a historic, architectural, artistic and tourism jewel, proved once again to be the ideal stage for a festival, such as EXIT. Besides magnificent atmosphere, which was felt by all the visitors and participants of the festival, the Fortress provides high quality acoustics with the possibility to stage different events very close to each other but without mixing the sound. (www.exitfest. org.).

EXIT has grown into an efficiently organised festival featuring some most prominent music celebrities, without losing its most prominent feature worldwide, its awesome atmosphere. What makes the EXIT ten years later is the music as a way of recognizing differences and joining similarities, thousands of young people ready to be creative and make the world a better place, the unusual and mysterious ambience of the fortress and more than 500 music performers on 20 stages.

The list of the musicians who have performed at Exit includes: Beastie Boys, Pet Shop Boys, Billy Idol, Robert Plant, Snoop Dogg, The Prodigy, Iggi Pop, Massive Attack, Moloko, Cypress Hill, The Cult, Franz Ferdinand, Kosheen, Underworld, Fatboy Slim, White Stripes, Garbage, Stereo Mc's, Slayer, Roni Size, Manu Chao, $N^{*} E^{*} R^{*} D$, Groove Armada, Paul Weller, Primal Scream, Sex Pistols, Richie Hawtin, Danny Tenaglia, Frankie Knuckles, John Digweed, Eric Prydz, Carl Cox, Eric Morillo, David Morales, Roger Sanchez, Timo Mass, LTJ Bukem, Felix The Housecat, Sasha, Sven Vath, Deep Dish, Francois K, Tiga, Axwell, Laurent Garnier, etc. In addition, the social engagement has included various initiatives: the initiative to abolish visa regime, fighting against human-trade, etc. (http://www.blic. rs/forum/index.php?topic=3137.0).

Significant factor of EXIT festival attractiveness are the reasonable prices of accommodation, food, refreshments and tickets for the festival. The tickets for EXIT festival (a four-day ticket) - limited number of tickets. When all the tickets for the promotional price are either booked or sold, the new price of the tickets is increased to about 110 Euros. 


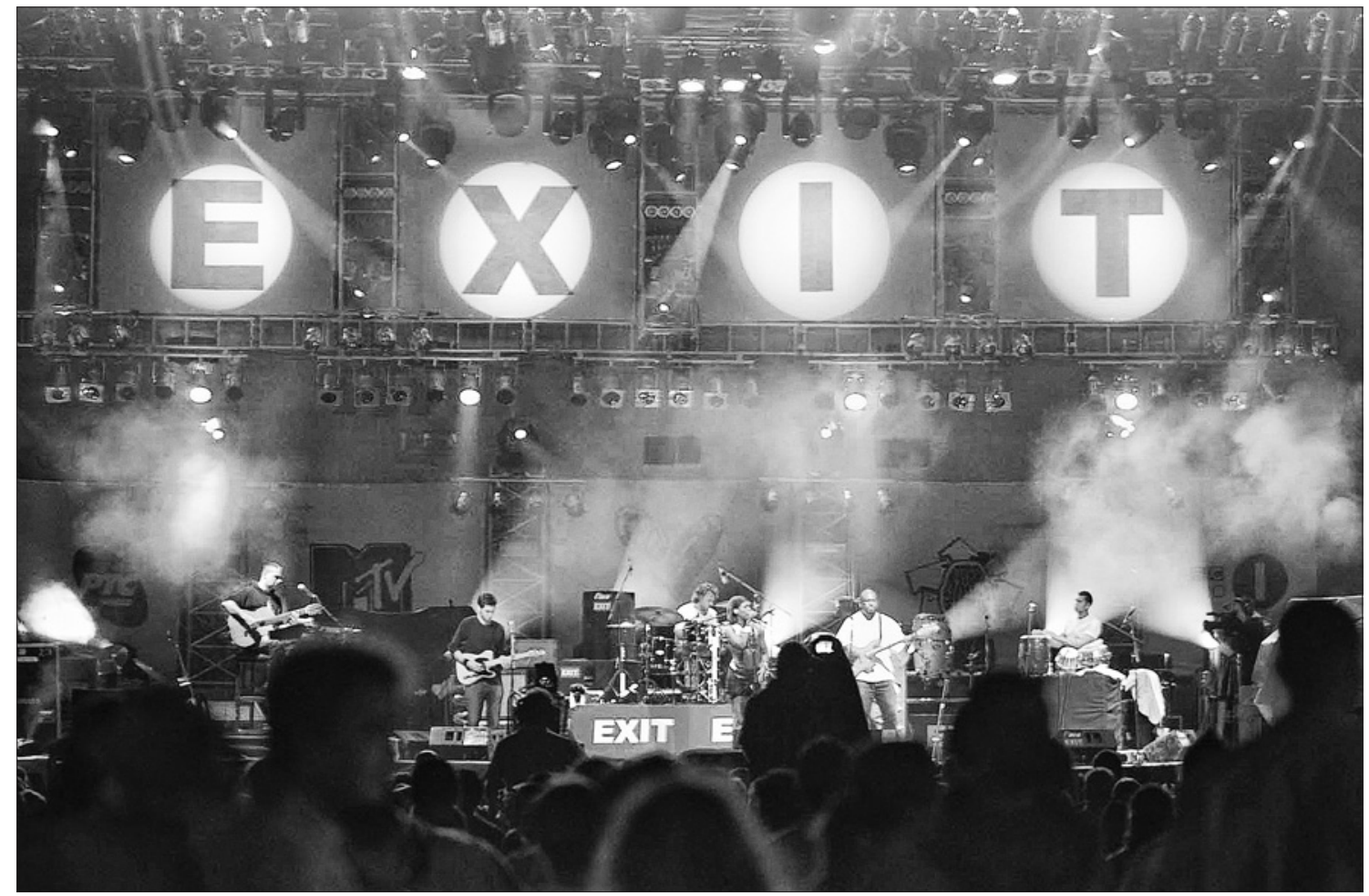

Photo 1 The main stage at the EXIT Festival; Photo by: D. Gojić

According to the festival organisation, all the four-day tickets have been sold for the last two years.

Moreover, the attractiveness of the festival rests on the festival venue. The town of Novi Sad, the second largest town in Serbia and the capital of the Autonomous Province of Vojvodina, has a remarkable accommodation capacity in hotels, motels and pensions. The festival organisation designates the area for a campsite for accommodation of several thousands visitors at utterly reasonable prices. Novi Sad is a town rich in numerous tourist attractions. Also, the City atmosphere is importan factor which attract tourists to visit Novi Sad. The City atmosphere is directly connected with Novi Sad inhabitants because they are extremely cultural, tolerant and hospitable (Blesic, Wallranbenstein, Devic, 2008). Especially interesting during summer months is the city beach Štrand, the largest and most beautiful beach on the Danube.

\section{The Petrovaradin Fortress}

One of the most beautiful and most significant historical monuments in Novi Sad is the Petrovaradin Fortress. It is situated on the right bank of the Danube river, on the territory of Petrovaradin municipality, the town area of Novi Sad, which is the capital of Vojvodina Province in the north part of Serbia. The position of the fortress provides a supreme visual experience whichever direction you watch either from its walls or towards the fortress itself. The Petrovaradin Fortress represents a complex military defence system, which once consisted of six mainly attached units. It had an extraordinary military importance in the $18^{\text {th }}$ century serving as a defence rampart against the Turkish Empire.

Prince Croy laid the corner stone for the Fortress on $18^{\text {th }}$ October 1692 on orders of the Habsburg Emperor Leopold
I at the place of the future Leopold's Bastion. The works on the Fortress lasted from 1692 to 1780 . The idea for its project belonged to the French warrior, architect and writer Marquis Sebastien Le Prestre de Vauban who lived during the reign of Louis XIV. He was famous for fortresses spanning on large areas with underground galleries. With the increase of importance of firearms, fortified underground becomes more strategic as well as the Petrovaradin Fortress, which and was therefore dubbed "The Gibraltar on the Danube" (Markovic, 1996).

The basis of the Petrovaradin Fortress was diorite rock, which observed from the Danube side gives the fortress specific and magnificent appearance. There are three distinguished levels: upper, middle and lower connected with plateaus and slopes. The total altitude difference is about 60 $\mathrm{m}$. The relief highly influenced the construction, and later function of certain parts of the Fortress (Programme of revitalization for the Petrovaradin Fortress, 1996).

The construction of the Fortress undergone certain phases, stretching from the top of the rock towards its bottom, according to the project of the fortification during the reigns of Habsburgs Leopold I, Joseph I, Carl IV, Maria Theresa and Joseph II who all received their own bastions (Vranic, 1963)..

The Petrovaradin Fortress covers the area of over 80 ha and stretches on three levels. Practically, it consists of three detached fortification systems: Upper, Middle and Lower Fortress. During the first phase of construction, the Upper plateau was finished with all the objects and bastions. Within the first two years, the entity of the Upper fortress was completed with five bastions: Leopold's, Pope Innocent's, Joseph's I, Ludvig's and Maria Theresa's (Gavanski, 1979).

The Fortress has been proclaimed the cultural asset of highest importance and falls to the category of unique cul- 


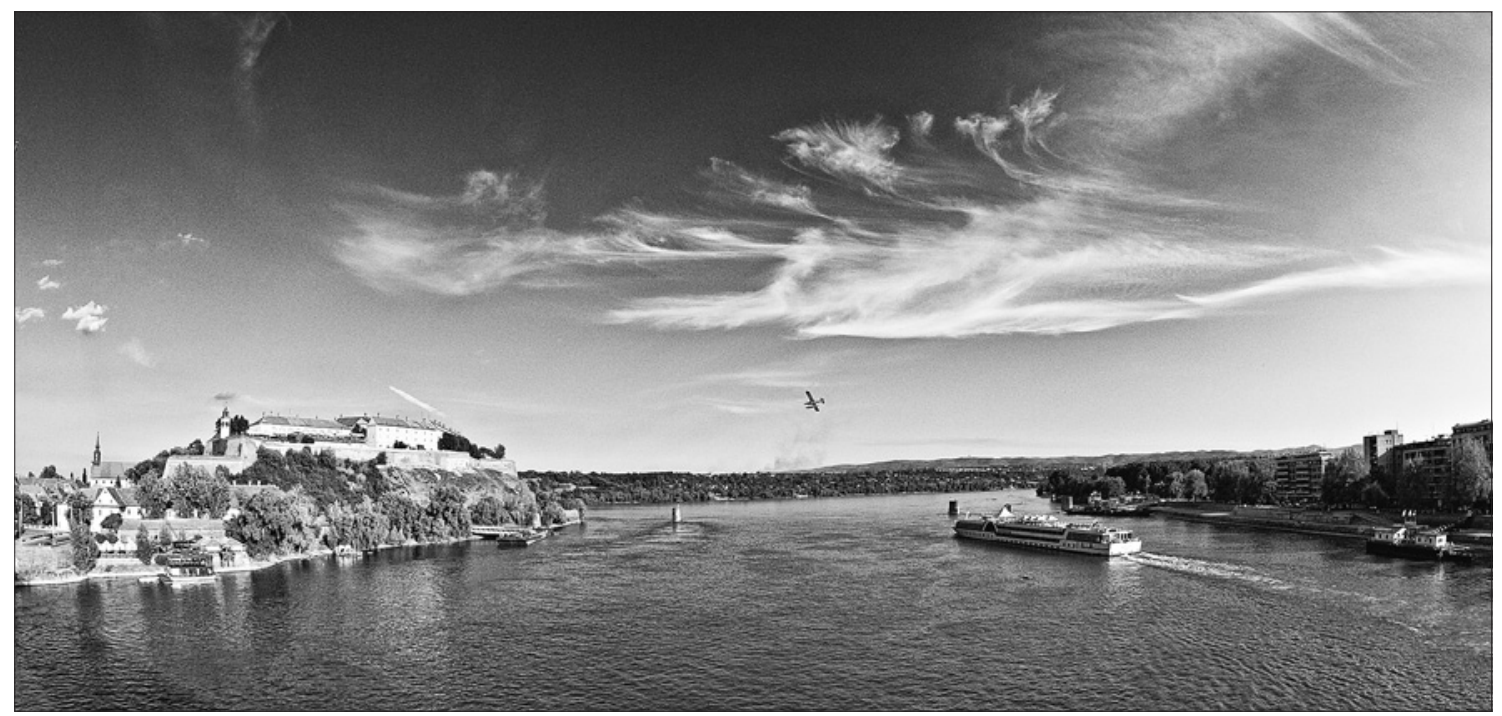

Photo 2 The Petrovaradin fortress on the Danube; Photo by: L. Lazić

tural and historical objects in fortification masonry. It features prominent architectural, artistic and ambience values with a special emphasis given to its cultural history.

Today, The Petrovaradin Fortress houses the Academy of Arts, The City Museum of Novi Sad, Historical Archives, Equestrian club, Shooting club, luxurious hotel Leopold and several restaurants with the panoramic view of Novi Sad. Underneath the Fortress, there is a network of catacombs, available for guided sightseeing tours. Moreover, there are numerous ateliers of renowned artists of Novi Sad, willing to present their works of art to visitors.

\section{Research}

The main goal of all the marketers entering the market today is attracting and retaining consumers.

Satisfaction (pleasure) is the key element in keeping the present clients (visitors) and attracting new ones. Tourists' pleasure with purchased tourist product or service results in two basic benefits: increase of tourists' loyalty and positive word-of-mouth marketing of the tourist destination (Maricic, 2002).

The concept of tourist satisfaction is one among those provoking the least differences and contrasts within definition process. Tourists are satisfied when tourist products or services fulfil or surpass their expectations (Gerson, 1994). Every visitor individually creates the expected value of a service. The proper measurement of successfulness of a service or a product is obtained when the experienced (perceived) values meet the expectations. Taking into account heterogeneousness of services in hotel industry and personal dimension of their realisation, the achievement of total satisfaction is extremely difficult (Kosar, 2002).

The main goal of every programme for tourist satisfaction measurement is monitoring of attitudes and perception of tourists concerning quality of tourist product and services in a tourist destination, tourist enterprise and selection of adequate feedback system on tourists' experiences (Maricic, 2002). Active relationship towards various tasks, complaints and suggestions of tourists enables a tourist enterprise to increase the level of their satisfaction and loyalty and helps it differentiate from the competition. The best approach is to make permanent contacts with tourists and keep them informed about new offers and efforts the tourist enterprise makes to adequately meet their needs and wishes (Hanna, Wozniak, 2001).

Since EXIT festival has been proclaimed among the best music festivals in Europe by both the media in Europe and the visitors, there is a need to track visitor pleasure (satisfaction). Measuring and tracking visitor satisfaction will help answer the question whether the visitors are satisfied with the festival and to what extent. In addition, it can be estimated which elements of the festival the visitors are satisfied with, or whether there any elements that the visitors are dissatisfied with. Based on those findings, the organizers may react by correcting certain mistakes, prior to escalation of dissatisfaction.

A question arises about what is that makes a festival of this type that attractive to large numbers of visitors. Our research commenced from those elements of the festival that the interviewed tourists from the UK described as attractive (people, programme, weather conditions, venue and prices). The fact is that any relevant research has not been conducted on tourist behaviour (EXIT visitors) yet. Therefore, this research might be considered a pilot research, whose results may aid or direct further research.

There are various attempts of measuring the satisfaction or dissatisfaction level of tourists regarding the selected tourist product. The measurement difficulties arise from the fact that the level of satisfaction is dependent upon tourist aspirations and expectations. Therefore, there is a belief that the satisfaction measurement is highly subjective. The most objective estimation may be obtained by application of a questionnaire on tourist satisfaction. Such questionnaires investigate general rates of tourist offer quality, estimate specific attributes of tourist offers and problems that emerge in a tourist destination during the utilisation of tourist product or services, as well as the models of problem solving (Maricic, 2002).

For this research, the authors-researchers have determined to investigate the visitor satisfaction with the follow- 
ing elements of the festival: quality of music performers, ticket price and services, socialization, ambience of the festival - the Petrovaradin Fortress and the ambience and features of Novi Sad. The working hypothesis was that the music festival that had been proclaimed for one of the vest in Europe and the world offers to its visitor's maximum satisfaction, i.e. a combination of high satisfaction with all the elements of the festival. Concurrently, there is a hypothesis that the specificity of the ambience of the Petrovaradin Fortress largely contributes to overall attractiveness of the festival.

At the same time, regardless the indisputable success of EXIT festival, professionals from various fields in Novi Sad and Vojvodina insist on dislocation the festival to a different location. Some professionals (in the fields of culture, history and archaeology) assume that EXIT festival highly damag es the Petrovaradin fortress, which is an object of great cultural importance. They suppose the festival might be held at a different location in Novi Sad or in the surroundings. Due to those frequent appeals, the authors and researchers determined to investigate the attitudes and opinions of the festival visitors on this topic. What is the opinion of the visitors: Is the fortress the right venue for the festival and Would EXIT be as attractive if held on a different location?

\section{Empirical part}

\section{Aim of the research}

- Regarding the questionnaire prepared for the research it should be established to what extent the visitors of EXIT festival feel satisfied with the ambience of the Petrovaradin Fortress, in comparison to the degree of satisfaction with other elements of EXIT festival (performers, prices, atmosphere, Novi Sad).

- Regarding the questionnaire prepared for this research, it should be established to what extent the visitors of the festival agree with the statements in the questionnaire referring to the Petrovaradin Fortress as the festival venue.

- On the basis the questionnaire, it should be established to what extent the visitors of the festival are introduced to cultural and historical importance of the Petrovaradin Fortress.

\section{Sample}

The population researched consists of the visitors to EXIT festival from July $10^{\text {th }}$ to July $13^{\text {th }} 2008$. Since the research has not covered the total visitor's population, an applicable sample of the visitors who have agreed to take part in the research has been chosen.

It is impossible to estimate whether the sample is representative, since the population researched is variable in all segments. The data on the number and the structure of the visitors of EXIT festival is mainly given by the organizers, which may not always reflect the valid data.

The sample taken for this research consists of 252 respondents. Among them 127 (50.3\%) are males, and 125 $(49.7 \%)$ are females. The number of foreign visitors in the sample is 151 (59.9\%); the number of visitors from Serbia is $79(31.3 \%)$, whereas the number of visitors from former Yu- goslav republics is $22(8.7 \%)$. The largest percentage of foreign visitors comes from Great Britain $44.8 \%$, whereas visitors from Germany make only $3.2 \%$ of the sample. The respondents from 20 different countries (European countries, the United States of America, Australia, Panama and South African Republic) took part in the research. Mean age of respondents is 23.56. The youngest respondent is 16 and the oldest is 45 . The educational structure showed the domination of students and visitors holding a university degree making the total above $70 \%$, whereas only 3 respondents (1.2\%) declared themselves as attaining only primary education.

\section{Instrument of the research}

The instrument used in this research is a questionnaire prepared by the authors, i.e. researchers. The questionnaire consists of four parts. The first part consists of socio-demographic characteristics of a respondent (gender, age, country of origin, level of education attained). The second part consists of the list of five elements of EXIT festival (quality of the performers, ticket price and complementary services, socialization, ambience of the venue - the Fortress and the ambience of Novi Sad). The respondents express opinion on the degree of their satisfaction of the cited elements of the festival by the help of five-point Likert scale by circling the appropriate number (1 completely dissatisfied, 5 completely satisfied). The third part consists of four statements, which refer to the ambience of the Petrovaradin Fortress, as the festival venue. The respondents circle the appropriate number on five-point Likert scale (1 - completely disagree, 5 - completely agree) to express the degree of their consent with the statements. The fourth part of the questionnaire attempts to estimate the level of knowledge and information on the Petrovaradin Fortress as a cultural asset.

\section{Research procedure}

The research was of individual type. The authors-research ers prepared the questionnaire form in English and Serbian language. The inquirers have been trained in advance for conducting the questionnaire in EXIT's camp (which hosts about 10,000 visitors) and at the Petrovaradin Fortress. The inquirers distributed the questionnaire to the visitors who showed interest in taking part in this research. Then the respondents filled out the questionnaire forms by themselves and returned them to the inquirers. The questionnaire form was anonymous. The total of 252 questionnaire forms was properly filled out. The authors-researchers classified the questionnaire forms; the data were transferred to a PC and processed with the SPSS 11.5 for Windows.

\section{Data Processing and Results Interpretation}

In this paragraph, the analysis and results interpretation according to the aims of the research will be presented.

The first question from the questionnaire form to be analysed comprises the five elements of the festival (quality of the performers, ticket price and complementary services, socialization, ambience of the festival venue - the Fortress and Novi Sad). The respondents regarding their personal 
Table 1 Visitors' satisfaction with the elements of EXIT festival

\begin{tabular}{|l|l|r|r|r|r|r|}
\hline \multicolumn{2}{|c|}{} & $\begin{array}{c}\text { Quality of music } \\
\text { performers }\end{array}$ & $\begin{array}{c}\text { Prices of tickets and } \\
\text { complementary services }\end{array}$ & Socialization & $\begin{array}{c}\text { Ambience of the festival } \\
\text { venue - the fortress }\end{array}$ & $\begin{array}{c}\text { Outlook and } \\
\text { ambience of Novi Sad }\end{array}$ \\
\hline \multirow{2}{*}{$\mathrm{N}$} & Valid & 244 & 252 & 252 & 251 & 248 \\
\cline { 2 - 7 } & Missing & 8 & 0 & 0 & 4.70 & 4 \\
\hline Mean & 4.10 & 3.52 & 4.46 & 5 & 4.42 \\
\hline Mode & 4 & 5 & 5 & 1 & 5 \\
\hline Minimum & 2 & 1 & 5 & 5 & 1 \\
\hline Maximum & 5 & 5 & 5 & & 5 \\
\hline
\end{tabular}

satisfaction, by the help of five-point Likert scale, validated each of the five elements. The respondents expressed the degree of their satisfaction by circling a number on the scale (from 1 - completely dissatisfied to 5 completely satisfied).

The table 1 shows that four out of five elements received the average score higher than 4 (4- mainly satisfied). In an expectant manner, the visitors estimated all the elements of the festival regarding their satisfaction as satisfactory on average. It was only for the element tickets price and complementary serviced that it received the average score lower than $4(M=3.52)$.

One of the most significant indicators in this research is exactly the average score of satisfaction with the ambience of the festival venue - the Petrovaradin Fortress $(\mathrm{M}=4.7)$ which also received the highest score of satisfaction among the festival elements. Such high average score of satisfaction supports the fact that the organisers of EXIT festival have hit the bull's eye by choosing this location for the festival venue.

Table 2 clearly shows that the majority of the respondents (94.5\%) expressed their satisfaction with the ambience of the festival venue. The majority comprises the satisfied somewhat respondents (17.5\%) and completely satisfied respondents (77.3\%). Only 1.6\% of respondents expressed dissatisfaction with the ambience of the festival venue, i.e. $0.8 \%$ of the respondents were completely dissatisfied and $0.8 \%$ somewhat dissatisfied with the ambience of the festival venue. The $3.6 \%$ of respondents felt indifferent towards the ambience of the festival venue, since they priorities were music and socialization at the festival independently of the ambience.

High degree of satisfaction of visitors with the ambience of the festival venue did not involve the fact whether certain groups of respondents differ according to their degree of satisfaction. In order to obtain such data we divided the respondents into four groups. The first division was done according to the country of residence. Regarding the country they arrive, the visitors are divided into three groups: foreign visitors, domestic visitors and visitors from the former Yugoslav republics.

Using the method of the F-test for investigation of significance of mean value differences it may be concluded with $95 \%$ accuracy that there are no statistically significant dissimilarities in the degree of satisfaction with the ambience of the festival venue between those three groups of respondents $(\mathrm{F}=0.057 ; \mathrm{df}=2 ; \mathrm{Sig} .=0.944)$.

When $\mathrm{F}$ test is applied to testing the differences between different groups of respondents according to their level of education attained, the results obtained indicate that none
Table 2 The degree of satisfaction with the ambience of the festival venue - the Petrovaradin Fortress

\begin{tabular}{|l|r|r|r|r|}
\hline & Frequency & \multicolumn{1}{l|}{$\%$} & Valid \% & Cumulative \% \\
\hline $\begin{array}{l}\text { completely } \\
\text { dissatisfied }\end{array}$ & 2 & 0.8 & 0.8 & 0.8 \\
\hline $\begin{array}{l}\text { dissatisfied } \\
\text { somewhat }\end{array}$ & 2 & 0.8 & 0.8 & 1.6 \\
\hline undecided & 9 & 3.6 & 3.6 & 5.2 \\
\hline $\begin{array}{l}\text { satisfied } \\
\text { somewhat }\end{array}$ & 44 & 17.5 & 17.5 & 22.7 \\
\hline $\begin{array}{l}\text { completely } \\
\text { satisfied }\end{array}$ & 194 & 77.0 & 77.3 & 100.0 \\
\hline Total & 251 & 99.6 & 100.0 & \\
\hline Missing System & 1 & 0.4 & & \\
\hline Total & 252 & 100.0 & & \\
\hline
\end{tabular}

Table 3 Mean satisfaction with the ambience of the festival venue for three groups of respondents

\begin{tabular}{|l|c|}
\hline Visitors & Ambience of the festival venue - the fortress \\
\hline domestic & 4.68 \\
\hline foreign & 4.71 \\
\hline ex -Yu & 4.68 \\
\hline Total & 4.70 \\
\hline
\end{tabular}

of the respondent groups does statistically differ from the other groups regarding the level of satisfaction $(\mathrm{F}=0.57$; $\mathrm{df}=3$; Sig.=0.636). In addition, the application of the t-test for testing differences in mean satisfaction between male and female respondents, the conclusion may be drawn that there are no statistically relevant differences in mean satisfaction by the ambience of the festival venue between two groups of respondents of different gender $(t=1.324 ; d f=249$ : $\mathrm{Sig}=0.187$ ).

It may be concluded that the visitors, regardless the country of residence, gender, or education level, do not significantly differ regarding the statistical degree of satisfaction with the ambience of the Fortress, and that the respondents mainly feel satisfied with the Fortress as the festival venue, regardless their socio-demographic characteristics.

Interestingly enough, the respondents express the lowest mean satisfaction with the festival elements: ticket price and complementary services. Foreign visitors are satisfied on average $(M=4.14)$ with this element, the visitors from ex-Yugoslav republics are less satisfied $(M=3.50)$, whereas the domestic visitors are mostly dissatisfied $(\mathrm{M}=2.34)$ with this element. The application of the F-test for testing differences between independent samples (visitors: foreign, 
Table 4 The survey results of EXIT festival visitors' attitudes

\begin{tabular}{|l|r|r|r|r|r|}
\hline & N & Min. & Max. & Mean & $\begin{array}{c}\text { Std. } \\
\text { Deviation }\end{array}$ \\
\hline $\begin{array}{l}\text { Petrovaradin } \\
\text { fortress is an } \\
\text { excellent venue for } \\
\text { the Exit festival. }\end{array}$ & 51 & 1 & 5 & 4.64 & 0.785 \\
\hline $\begin{array}{l}\text { The area of } \\
\text { Petrovaradin } \\
\text { fortress provides } \\
\text { extraordinary } \\
\text { experience for the } \\
\text { visitors }\end{array}$ & 51 & 1 & 5 & 4.61 & 0.669 \\
\hline $\begin{array}{l}\text { The Exit festival } \\
\text { should be dislocated } \\
\text { from the fortress }\end{array}$ & 51 & 1 & 5 & 1.71 & 1.214 \\
\hline $\begin{array}{l}\text { The Exit festival } \\
\text { would be as } \\
\text { attractive as if } \\
\text { it took place on } \\
\text { another location }\end{array}$ & 51 & 1 & 5 & 1.98 & 1.210 \\
\hline Valid N (listwise) & 51 & & & & \\
\hline
\end{tabular}

ex-Yu and domestic) may assume with 95\% accuracy that these dissimilarities in satisfaction are statistically relevant $(\mathrm{F}=73.618 ; \mathrm{df}=2$; Sig. $=0.000)$. The application of Scheffe test has established that there are three homogenous subsets of data (foreign, ex-Yu and domestic).

The portion of the questionnaire, referring to the Petrovaradin Fortress as the festival venue, comprises the four statements on this topic. The researchers aimed at obtaining the attitudes of the festival visitors. The respondents task was to express their attitudes by circling one of the numbers on five point Likert scale (1-completely disagree, 5 - completely agree).

In connection with the attitudes about the Petrovaradin Fortress (Table 4), the respondents expressed their consent with the first two statements. This consent refers to the fact that the visitors agree that the Petrovaradin Fortress is an excellent venue for the festival $(M=4.64)$, and its ambience offers unique experience for the visitors $(M=4.61)$. Compared to the fact that EXIT festival should be dislocated, the visitors expressed a certain degree of disagreement $(M=1.71)$. Moreover, the visitors expressed their dissatisfaction on the statement that the festival would be as attractive if held in a different venue $(M=1.98)$. The results obtained on the attitudes of visitors of the festival clearly define that the visitors are mainly interested in the fact that the festival continues to be held at the Petrovaradin Fortress and can not find another venue for the festival to make it as attractive as today. As it has already been highlighted, experts in the field advocate the preservation of the Fortress and reduction of unfavourable conditions by dislocating the festival. On the other hand, the visitors of the festival disagree with the idea. The visitors are of the opinion that dislocation of the festival would have negative effect on the attractiveness of the festival. The most urgent is to answer this question: Is there a possibility to maintain the attractiveness of the festival and preserve the Petrovaradin Fortress at the same time?

Although the respondents were mainly satisfied with all elements of the festival, the results of attitude measurement illustrate that the visitors would not like the venue of the festival to be changed in the future since it would not be as attractive if held at a different location. Such results were most probably obtained because the visitors were familiar with this form of the festival at its present location, i.e. there was no opportunity for them to visit the festival at a different location. Even though the visitors expressed high satisfaction with the quality of performers, socialization and ambience of Novi Sad, they would not like the festival to be dislocated from the Petrovaradin fortress. In case it happened, their level of satisfaction with the festival elements would be disputable. The result of visitor attitude measurement is particularly significant showed that they supposed EXIT festival would not be as attractive if held at a different location. Since the measurement of attitudes is one of the methods in predicting respondents' future behaviours, in this particular case there is a hypothesis that dislocation of the festival would have a negative impact on its attractiveness, and presumably on attendance and visitors' satisfaction. In addition, the result of attitudes measurement directly implies that the ambience of the Petrovaradin fortress is an essential element of the attractiveness of the festival.

The attitudes of visitors showed interesting statistic differences (Table 5), by the application of the F-test between the mean degree of agreement between domestic and foreign visitors regarding the Petrovaradin Fortress as the ideal venue for EXIT festival $(\mathrm{F}=7.962 ; \mathrm{df}=2 ; \mathrm{Sig}=0.000)$. The visitors from former Yugoslav republics did not show significant variation compared to other two groups $(M=4.57)$ The visitors from Serbia, showed lower degree of agreement with the statement that the Petrovaradin Fortress is the ideal venue for the festival $(M=4.37)$, but significantly higher degree of agreement with the statement that EXIT festival should be dislocated. The results of attitude investigation seem to be the consequence of the aforementioned campaign in local media about the significance of the Petrovaradin Fortress and dislocation of the festival. On the other hand, foreign visitors have not been informed about the campaign, i.e. have not had the opportunity to think whether the festival endangers the Fortress.

The question in the last part of the questionnaire attempts to obtain the result whether the visitors are informed that the Petrovaradin Fortress is a cultural and historical asset of high importance. The answer to this question comprises two model answers: yes and no. The results are presented in Graph 1.

Almost two quarters of the respondents have been in formed about the fact that the Fortress represents a cultural asset of highest importance. Majority of the uninformed

Table 5 Mean values of an attitude measurement: the Petrovaradin Fortress is an excellent venue for EXIT festival for 3 groups of respondents.

\begin{tabular}{|l|l|l|l|}
\hline Visitors & Mean & N & Std. Deviation \\
\hline domestic & 4.37 & 79 & 1.064 \\
\hline foreign & 4.79 & 151 & 0.511 \\
\hline ex-Yu & 4.57 & 21 & 0.926 \\
\hline Total & 4.64 & 251 & 0.785 \\
\hline
\end{tabular}


Table 6 Three groups of visitors: Their informedness of cultural and historical significance of the Petrovaradin Fortress.

\begin{tabular}{|l|r|r|r|r|}
\hline $\begin{array}{l}\text { Do you know } \\
\text { that Petrovaradin } \\
\text { fortress is a cultural } \\
\begin{array}{l}\text { asset of highest } \\
\text { importance? }\end{array}\end{array}$ & domestic & foreign & ex-Yu & \multirow{2}{*}{ Total } \\
\cline { 2 - 5 } Yes & 75 & 87 & 14 & 176 \\
\hline No & $94,9 \%$ & $60,4 \%$ & $66,7 \%$ & $72,13 \%$ \\
\hline Total & 4 & 57 & 7 & 68 \\
& $5,1 \%$ & $39,6 \%$ & $33,3 \%$ & $27,87 \%$ \\
\hline
\end{tabular}

respondents comes from foreign countries. As high percentage as $94.9 \%$ domestic respondents have been informed about the significance of the Fortress, then follow respondents from former Yugoslav republics with $66.7 \%$ and $60.45 \%$ foreign tourists, as presented in Table 7. Although the foreign respondents seem the least informed about the significance of the Fortress, the fact that more than a half of the surveyed foreign visitors know something about the importance of this object is a promising one. The protection of the Fortress, which is the main goal of the organisers and the public, may be achieved through rendering continuous information to foreign visitors, especially those coming for the first time, about the significance of the Fortress. Finally, it is important to develop the awareness of the visitors to adjust their behaviour during their stay at the Fortress so that they do not endanger the cultural asset.

\section{Conclusion}

EXIT festival is one of the most significant cultural events organized in Serbia. It is held annually in mid July and lasts for four days at the Petrovaradin fortress. Since 2000, when it was first organized, it has been recording the increase in the number of visitors, particularly foreign visitors. Numerous music performers participated at the festival, among them the most famous musicians from the region and the world. Foreign journalists, visitors and mass media ranked the festival among the best festivals of this kind in the world. Apart from the participation of renowned musicians at the festival and reasonable ticket prices, certainly one of the most important elements for the attractiveness of the festival is the ambience of its venue.

The research concerning the importance of authentic ambience of the Petrovaradin Fortress as a factor of the attractiveness of EXIT festival was conducted on accidental sample, consisting of the visitors of the festival, who agreed to take part in the research. Based on the results obtained in the analysis of the satisfaction of the elements of EXIT festival, it is evident from the mean score, that the visitors showed high satisfaction with the ambience of the Petrovaradin Fortress. This element exactly is the one for which visitors expressed their highest satisfaction (pleasure). The lowest score of satisfaction, the respondents expressed for the ticket prices and complementary services. Within the analysis of the degree of satisfaction with the ambience of
Do you know that the Petrovaradin Fortress is a cultural asset of high importance?

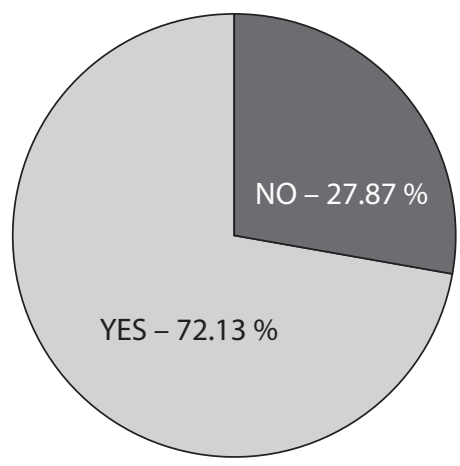

\section{Figure 1 Distribution of answers in percentages}

the festival venue, i.e. the Petrovaradin Fortress, it has been concluded that $77.3 \%$ respondents are completely satisfied with the ambience, whereas only $1.6 \%$ expressed dissatisfaction with the ambience.

Finally, based on the results obtained, investigating respondents' satisfaction and attitudes measurement, it may be concluded that the authentic ambience of the Petrovaradin Fortress is of high importance on EXIT festival attractiveness.

\section{References}

Baum, T., Hagen, L. 1999. Responses to seasonality, The experiences of peripheral destination. International journal of tourism research $1,299-312$.

Blešić, I., Wallrabenstein, K. Devic, M. 2008. Motivation of Novi Sad (Vojvodina, Serbia) visitors out of the tourist season. Geographica Pannonica12,1, 45-52.

Fajgelj, S. 2004. Methods of behavioural research. Centre for applied psychology: Belgrade, 359-380, 424-429, 510512, 539-542. (in Serbian)

Gavanski, Dj. 1978. The Petrovaradin Fortress in the events of the period 1848-1849. Collection of papers in History. Matica srpska, 18. Novi Sad. (in Serbian)

Gerson, R., F.1994. Measuring Costumer Satisfaction. Kogan Page, London.

Getz, D. 1997. Events management and Event Tourism. Cognizant Communications Corporation: New York.

Getz, D. 2007. Event tourism: Definition, evolution and research. Tourism management, 1-16.

Hadžić, O. 2005. Cultural tourism. Faculty of Science, Department of Geography, Tourism and Hotel Management. Novi Sad, 66,278. (in Serbian)

Hanna, N., Wozniak, R. 2001. Consumer Behavior: An Applied Approach. Prentice Hall, New Jersey.

Kosar, Lj. 2002. Hotel Industry - theory and practice. HHS, Belgrade. (in Serbian)

Lee, Y., Lee, Ch., Lee, S. and Babin, B. 2008. Festivalscapes and patrons'emotions, satisfaction and loyalty, Journal of Business Research 61. 56-64.

Maričić, B. 2002. Consumer behaviour. Savremena administracija. $6^{\text {th }}$ revised edition, Belgrade. (in Serbian)

Marković, Z. 1996. Walking at the Petrovaradin Fortress. Tourist organization of Novi Sad, Novi Sad, 13, 39. (in Serbian) 
Pivac, T., Garača, V., Kovačević, D. 2007. The Role of the Music Festival Exit on the Social and Cultural Life in the Balkan Region in the Post-War Period. The $8^{\text {th }}$ International Joint World Cultural Tourism Conference 2007, Busan, 217-222.

Popović, V. 1996. The Petrovaradin Fortress - revitalization programme. JP "Urbanizam”. Novi Sad. (in Serbian)

Programme for revitalisation of the Petrovaradin Fortress, 1996. (in Serbian)

Stokes, R. 2008. Tourism strategy making: Insight to the events tourism domain. Tourism Management 29, 252-262.
Vranić, M. 1963. Petrovaradin. Matica Srpska. Novi Sad.(in Serbian)

www.uneptie.org/pc/tourism

www.exitfest.org

http://www.vesti.rs/Kultura/Caskanje-na-Tvrdjavi-TheBellrays.html

http://www.blic.rs/forum/index.php?topic $=3137.0$

http://www.blic.rs/forum/index.php?topic $=2682.0$

www.myexit.org/node/62613 